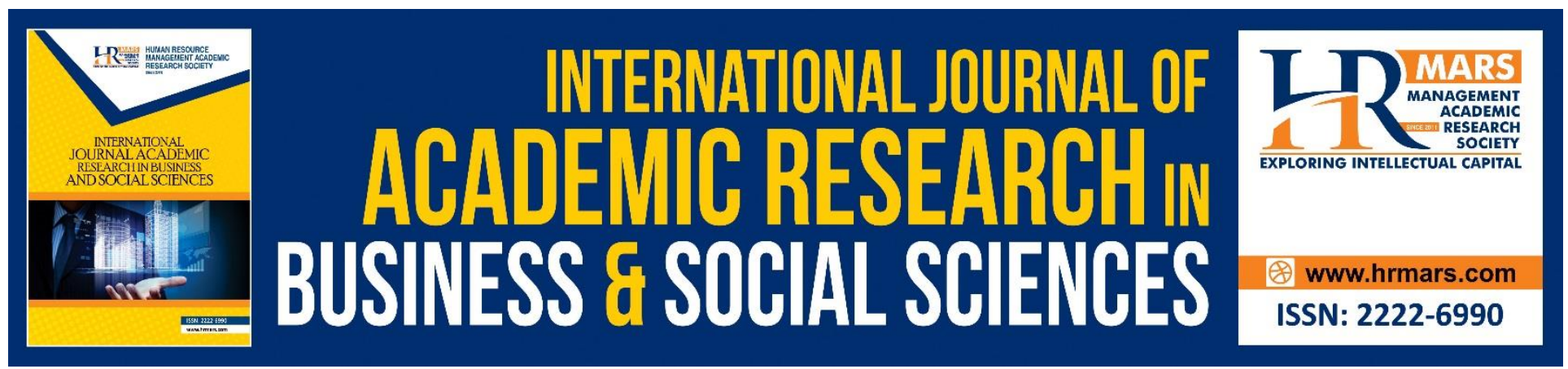

\title{
Manner Ethics Addressed in Existing Accounting Curriculum
}

\section{Haslinah Muhamad, Arfah Salleh \& Nor Aziah Abu Kasim}

To Link this Article: http://dx.doi.org/10.6007/IJARBSS/v8-i12/5148

DOI: $10.6007 /$ IJARBSS/v8-i12/5148

Received: 14 Nov 2018, Revised: 13 Dec 2018, Accepted: 15 Dec 2018

Published Online: 26 Dec 2018

In-Text Citation: (Muhamad, Salleh, \& Kasim, 2018)v

To Cite this Article: Muhamad, H., Salleh, A., \& Kasim, N. A. A. (2018). Manner Ethics Addressed in Existing Accounting Curriculum. International Journal of Academic Research in Business and Social Sciences, 8(12), 987-1012.

Copyright: (C) 2018 The Author(s)

Published by Human Resource Management Academic Research Society (www.hrmars.com)

This article is published under the Creative Commons Attribution (CC BY 4.0) license. Anyone may reproduce, distribute, translate and create derivative works of this article (for both commercial and non-commercial purposes), subject to full attribution to the original publication and authors. The full terms of this license may be seen at: http://creativecommons.org/licences/by/4.0/legalcode

Vol. 8, No. 12, 2018, Pg. 987 - 1012

Full Terms \& Conditions of access and use can be found at http://hrmars.com/index.php/pages/detail/publication-ethics 


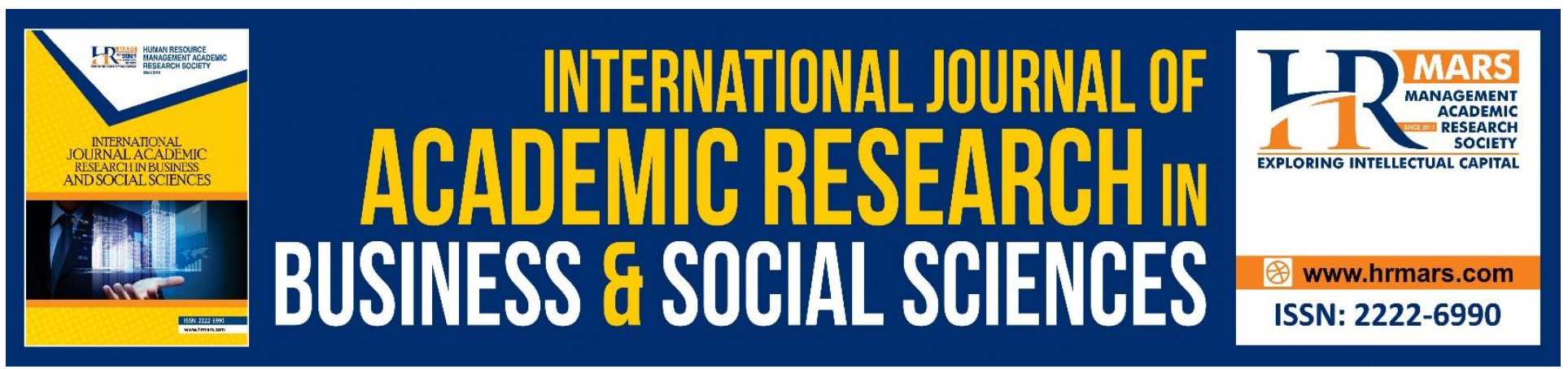

\title{
Manner Ethics Addressed in Existing Accounting Curriculum
}

\author{
Haslinah Muhamad $^{1 *}$, Arfah Salleh ${ }^{2} \&$ Nor Aziah Abu Kasim ${ }^{1}$ \\ ${ }^{1}$ Department of Accounting and Finance, Faculty of Economics and Management, Universiti Putra \\ Malaysia, Serdang, Selangor, Malaysia \\ ${ }^{*}$ Corresponding Author
}

\begin{abstract}
This study was conducted to examine the manner in which ethics was addressed in the existing accounting curriculum, the content of syllabus by international business schools and instillation of ethics elements in the local universities' vision and mission. Ethics syllabus of top 55 international business schools and 4 local universities web pages were reviewed. Summative content analysis was used to analyse the data. The results showed that not all universities involved in this study embedded ethics in their accounting curriculum as emphasised by IES 4, AACSB or MIA. In general, the content of current syllabi focuses on corporate governance. Issues regarding moral judgment, stewardship and accountability to shareholders are rarely discussed in ethics course as well as the element of human governance. This shows that the goal of ethics education is not on moral conversion, but on helping well-intentioned students to develop the skills necessary to identify and resolve their ethical dilemmas. Not all local public universities selected in this study encourage embedding ethics through their vision and mission. This is the sign that business schools do not show their commitment to centralise ethical responsibility at their corporate level.
\end{abstract}

Keywords: Ethics, Human Governance, Accounting Curriculum, Malaysia Public Universities

\section{Introduction}

Accountants face pressures to show and demonstrate that accounting is a highly credible profession (Low, Davey, \& Hooper, 2008) after the scandals including Enron, WorldCom and Tyco. To ensure that public confidence on the profession remains high, professional accounting bodies and regulators of the profession are proactive in combating unethical behaviour among practitioners. Ethics has naturally continued to generate a significant interest among practitioners and academics. However, the unethical behaviour continues with the involvement of business leaders with accounting background. As an example, former Tesco executives have been accused for "cooking the books" in a scandal that wiped $f 2 b n$ off the supermarket's total share value and sent "shockwaves" through the stock market. The supermarket's former finance chief, managing director and food commercial 
INTERNATIONAL JOURNAL OF ACADEMIC RESEARCH IN BUSINESS AND SOCIAL SCIENCES Vol. 8, No. 12, Dec, 2018, E-ISSN: 2222-6990 @ 2018 HRMARS

head were charged with fraud for abusing position and false accounting (Wylie \& Wardle, 2017). All three have pleaded not guilty, and the nature of their defences will only become clear at the forthcoming trial. In addition, the story of Malaysia's 1MDB has shaken the world of finance. The Malaysian Institute of Accountants (MIA) is currently investigating KPMG and Deloitte, the two accounting firms involved in signing off the accounts of troubled state fund 1Malaysia Development Berhad (1MDB). The investigations centre on whether or not the auditors had breached the Accountants Act when signing off the 1MDB's accounts between 2009 and 2014 (The Straits Times, 2018)

\section{Problem Statement and Research Questions}

The need and importance of ethics in accounting profession for national professional bodies to increase business reputation as well as reduce criminal activities and fraud have been emphasised by Jaijairam (2018) in a recent study. Given that professional conduct is lack of human values and ethics is the core to accounting professionalism, it is no surprise that the focus of attention has now shifted back to the manner in which accountants are trained and educated. The argument is that if potential accountants are well-trained to internalise good values, they could bring along such values to their professional lives; hence, practising ethical behaviour. The critics on education for being contributed to the corporate reporting scandals by discharging poor quality of education for the profession have been made by previous scholars (Low et al., 2008; Jackling et al., 2007; Power, 1991; Lehman, 1988; Gray et al., 1987). According to Amernic and Craig (2004, p.343), "one of the causes of the seemingly never-ending parade of accounting scandals and unexpected company collapses is the inadequacy of university curricula and business education". The accounting programmes are also said to be dominated by the learning of techniques and rules (Boyce, 2008; Sikka, Haslam, Kyriacou, and Agrizzi, 2007); thus, very little attention is given to instilling values, ethics and integrity (Sikka et al., 2007). Additionally, Glover and Aono (1995) highlighted that the defects in the education system is probably responsible for the behavioural problem of lack of ethics, which in turn led to accounting fraud. Besides, Haberman (2003) posited that detecting accounting fraud alone will not end the problem of misbehaviour; instead, focus has to be geared towards finding the mechanism to prevent further unethical practices. Given that ethical behavioural malfunction is a major social problem, it has been argued that the issue of accounting fraud has to be tackled from its root through education (Thomas, 2012). This paper seeks to examine the manner in which ethics is addressed in the existing accounting curriculum.

Accounting education has been said to have failed in developing students' intellectual and ethical maturity (Gray et al., 1994; McPhail, 2003) and in producing accounting graduates with characteristics of ethical behaviour (Bunker and Casey, 2012; Salleh and Ahmad, 2012; Amlie, 2010; Gioia, 2003; Plimmer, 2002). The fact that ethics has been claimed to be embedded throughout the curriculum exacerbated the issue of observation since only a longitudinal interpretive study could capture the ambience of a classroom where the effort to instil ethics is made. What is largely available and is the literature highlighting the failure of accounting education in inculcating ethical behaviour among accountants. Therefore, the need in finding a solution to address ineffective ethics education in accounting remains huge. 
Scholars argued a lack of human element in accounting ethics education (McPhail, 2001). As a result, a call to shift the rule based stratagem of corporate governance to principle based or human based governance has been made (IFAC, 2006c; Anwar, 2007). In 2009, on the basis of reception of principle based governance, the Malaysian Institute of Accountants (MIA) introduced the concept of human governance. Consequently, initiatives to incorporate human governance in the continuing professional workshop sessions have begun. The benefit of bringing in human governance into Ethics courses in the Accounting curriculum at Malaysian universities has been recognised by MIA through the President's speech at the National Accountants Conference 2009 when he challenged the Malaysian academicians to introduce human governance into the accountancy curriculum (Accountants Today, 2009). MIA has even set up a dedicated website (http://www.mia.org.my/at/at/200812/04.pdf and http://www.mia.org.my/at/at/2009/01/03.pdf) solely for disseminating the relevant conceptual papers and documentations on human governance. MIA also has a focus to engage the Ministry of Higher Education as the custodian of higher education in Malaysia in the agenda of bringing human governance into academia. Human governance in ethics education is more concerned with building an ethical character, which is on the development of spiritual side of human being rather than mere physical aspect (Salleh and Ahmad, 2012). The objective of accounting ethics education may require a different content, ways of delivery and assessment methods. However, there is no first step taken in responding to the challenge with no empirical study focusing on human governance in accounting education. As such, this study explores the existence of any human governance elements that are inculcated into ethics education in accounting curriculum.

According to Apostolou, Dull and Schleifer (2013), motivation from external and internal pressure is important to incorporate ethics in accounting curriculum. The need of ethics has been required by external pressures (accreditation bodies such as MIA and AACSB). The need of ethics should be also expressed within universities to show their commitment towards developing ethical behaviour among students (internal pressure). As such, the study objective is "to provide an overview of how ethics are currently embedded in accounting education curriculum by institutions". Reviewing documents and webpages constitutes the main data sources. The data inquiry was directed by basic, exploratory questions as follow:

1. How ethics are currently embedded in accounting education of international and local universities?

2. Is there any human element (affective education) embedded in ethics course offered by international and local universities?

3. How Malaysia's public universities embedded ethics through their official pronouncement?

\section{Literature Review}

Accounting and moral behaviour are synonymous because accountants play the role of custodians of public trust (Salleh and Ahmad, 2010; Dellaportas et al., 2005). Previous studies on Enron such as those by McPhail (2001), Geary and Sims (1994) as well as Loeb (1988) emphasised the need to enrich ethics in accounting education by inculcating morality or values to improve the moral behaviour and credibility among accountants. However, it was only in response to the Enron scandal that the 
International Federation of Accountants (IFAC) began to include education as a long-term strategy to tackle the issue of unethical behaviour among accountants by issuing the International Education Standards (IES). The attributes of ethical values needed by professional accountants are contained in the specially drawn IES 4 (effective January, 2006) on Professional Values, Ethics and Attitudes. In addition, IFAC issued the International Education Practice Statement (IEPS) 1 in 2006 to provide guidance in implementing IES 4 as well as in developing professional values, ethics and attitudes in accordance with that standard.

Later, IFAC released the Framework for International Education Standards for Professional Accountants (2008) that outlines the objective of accounting education, which is to develop competent professional accountants. To demonstrate competence in their role, a professional accountant must possess the necessary knowledge and skills including values, ethics and attitudes. Education, according to IFAC, is a systematic process aimed at acquiring and developing knowledge, skills and other capabilities of individuals; a process that is typically but not exclusively conducted in academic environments. The implication from this pronouncement is that all member bodies are obliged to comply with the International Education Standards for Professional Accountants and other IAESB Guidance including the Framework for International Education Standards for Professional Accountants. The series of pronouncements made by IFAC has exposed the importance of education as a means to inculcate ethics.

Consistent with the philosophy of the IFAC on the role of accounting education in inculcating ethics, the Ministry of Higher Education of Malaysia in 2006 revised the Reassessment Report on Accounting Programme offered by Malaysian Public Universities (Hala Tuju 2) to require that these educational institutions incorporate 14 learning outcomes into their respective accounting degree curriculum, one of which is the demonstration of students' ethical behaviour.

Even after the pronouncement of relevant educational standards on ethics by the IFAC, scholars continue to argue the need to re-examine the types of educational system that produce accounting professionals who, consciously or otherwise, appear to act unethically (Boyce, 2008; Low, et al., 2008). This is because evidence suggested that accounting education is partly guilty of failing in developing students' intellectual and moral abilities abounds (Amernic and Craig, 2004; Swanson and Frederick, 2003; McPhail, 2001). Low et al. (2008) argued the lack of morals in 'educated people' has contributed to the recent financial reporting scandals and corporate frauds.

There are extensive studies available on ethics education in accounting curriculum emanating from developed countries particularly the US, the UK and Australia. Evidence from the US suggests a decline in accounting ethics education with a reduction in dedicated courses in ethics (Dellaportas, Kanapathippillah, Khan, \& Leung, 2014). In addition, the decline was encouraged by the flexibility of the Association to Advance Collegiate Schools of Business (AACSB) standards, which requires fewer stand-alone ethics courses offered starting from 2007 (Blanthorne, Kovar, \& Fisher, 2007). 
In the UK, the extent of ethics education is increasing and similar to the US, rather than deliver ethics subject matter as a stand-alone course, the teaching of accounting ethics in the UK appeared to be embedded in existing courses typically financial accounting and auditing (Dellaportas, Kanapathippillah, Khan, and Leung, 2014; Ghaffari, Kyriacou, and Brennan, 2008). As in the US, corporate financial scandals have been found as a major driver for prompting the development of accounting ethics education offered by universities in the UK (Dellaportas, Kanapathippillah, Khan, \& Leung, 2014).

Meanwhile in Australia and New Zealand, only $4 \%$ of institutions offer ethics as a stand-alone course in undergraduate accounting programmes with none at the graduate level (Dellaportas, Kanapathippillah, Khan, \& Leung, 2014). 'Auditing' and 'Accounting Theory' represent popular courses for integrating ethics. Proponents of a separated ethics dedicated course argued that undergraduate students should have at least one well organised, reasonable long course in accounting ethics to grasp the seriousness and complexity of analysing and solving ethical problems (Gray, Bebbington, \& McPhail, 1994). In addition, a discrete course would signal universities' commitment to the importance of ethics education by making ethics as the centre of discussion rather than a supplementary subject (Fisher, Swanson, and Schmidt, 2011; Fisher and Swanson, 2005). There are limitations in a discrete or stand-alone course of ethics. The materials in a discrete course may be over theoretical or over simplistic, which may diminish the relevance of the topic to accounting students (Piper, Gentile, \& Parks, 1993). Similarly, entry-level students with minimal knowledge of functional aspects of business and accounting are less likely to effectively deal with the materials in the course of ethics. Consequently, any expectation of raising the ethical sensitivity of entry-level students will be unrealistic (McDonald \& Donleavy, 1995).

The study on need, relevancy and impact of ethics education on accounting profession has been made by Das (2015) as accounting deals with facts, figures and hard data with stakeholders relying on prepared financial information for taking their financial decisions. Hence it is important for accountants to be unbiased, competent and accurate. Scholars before Enron viewed that the goal of ethics education is not moral conversion (Oddo, 1997; Kerr and Smith, 1995; McDonald and Donleavy, 1995; Hosmer, 1988). In addition, Gandz and Hayes (1988) stated that the objective of ethics education should be to provide a framework identifying ethical issues analysed and resolved to the point of action. Ethics in accounting education is also considered as non-empirical, soft, or unscientific, apart from being seen as having no place in the curriculum of business schools (Cohen and Pant, 1989).

After Enron, as a result of the continuous accounting scandals and unethical behaviour among accountants, there is a call to adopt human or values-based corporate governance (Salleh and Ahmad, 2010 and 2009; Salleh and Ahmad, 2008; Arjoon, 2005). A rule-based mechanism that founded ethics in accounting education has been claimed to be ineffective (Kaptein and Schwartz, 2008; Helin and Sandstro"m, 2007). Textbook coverage of ethical theories has a western bias on the surface, which is inconsistent with the multi-cultural global accounting community (Tweedie et al., 2013). The primary function of current ethics education is to teach ethical systems of analysis, 
INTERNATIONAL JOURNAL OF ACADEMIC RESEARCH IN BUSINESS AND SOCIAL SCIENCES Vol. 8, No. 12, Dec, 2018, E-ISSN: 2222-6990 @ 2018 HRMARS

and not moral standards of behaviour (Dellaportas, Kanapathippillah, Khan and Leung, 2014). After reviewing the literature above, there were few questions made on current accounting ethics education. What is the goal of ethics education? Should it focus on moral conversion or just on providing a framework to identify ethical issues?

\section{New Directions for Accounting Education}

In dealing with unethical behaviour and reduced credibility of the accounting profession, McPhail, (2001) argued that the starting place for developing ethical or moral competency should be through accounting ethics education. High Level Group on the Modernisation of Higher Education (2013) recommended that institutions of higher learning and professional educators should work together to improve the quality of the profession. Armstrong (1993) argued that the positive effect of ethics education is on the quality of students' moral development.

Fixed legalistic mind-set is among the inadequacies of ethics in accounting education due the current practice of implementing rule-based education. Rule-based mechanism has been claimed to be ineffective in influencing ethical behaviour (Kaptein and Schwartz, 2008; Helin and Sandstro"m, 2007). In addition, Arjoon (2005) claimed that legal compliance mechanisms are insufficient and may not address the real and fundamental issues that inspire ethical behaviour. The insufficiency of codes of ethics as a legal compliance mechanism in influencing ethical behaviour has been also proven in various studies (Kapteinand Schwartz, 2008; Healy and Iles, 2002; Marnburg, 2000; Clark and Leonard 1998; Brooks, 1989). Similar result has been also found by the study in Malaysia setting by Mohammad et al. (2002), which concluded that the codes of ethics have little or no significant influence on the behaviour of accountants. They suggested four reasons behind the existence of such situation as lack of exposure to ethics and ethical issues, vagueness of the codes, absence of actual guidelines on solving conflicts and not having legal standing to subject offenders to prosecution in the court of law. Therefore, the current practice of rule-based approach in ethics accounting education with emphasis on compliance with the laws needs to be revisited or revised. Ryack, Mastilak, Hodgdon \& Allen (2015) suggested that, where possible, accounting educators may wish to teach principles based accounting prior to rules based accounting to mitigate potential anchoring by students and its effect on their accounting judgement. Owing to the continuous accounting scandals and unethical behaviour among accountants, there is a need to adopt human or values-based corporate governance to supplement the existing rule-based structure in promoting ethical behaviour in business (Salleh and Ahmad, 2010 and 2009; Salleh and Ahmad, 2008; Arjoon, 2005).

\section{The concept of Human Governance}

There is a proposal from practitioners in introducing the concept of human governance to the academic world especially at university level in Malaysia. Human governance is referred to as being human guided by a common set of principles inherent in every human being (Salleh and Ahmad, 2010). Before the human set the principles that later become a guidance in human action, we must know who we are (human being). This can be formulated by answering several questions such as "What is the nature of reality?", "Who am I?", "What is the world?", "How can one know what is real?" and "What is the truth and what is the criteria for its discernment?" The second has to do with 
the relationship between human and the reality they discerned. It can be formulated variously the questions including "What is the purpose of life?", "How should we relate to others?" and "How should we govern ourselves?" From time immemorial, cultures around the world have attempted to identify the qualities of what it means for a human being to do the right thing. It is beyond being moral, and being ethical; it is being fundamentally human. It is who we are, what we are intended when we were first created and what we need to become.

Driven from the reality view of Quantum physics, human governance views that everything is connected, from the smallest life to colossal galaxies. We are all ONE. But Oneness goes beyond the physical universe; it also includes all physical and nonphysical realities. If every person in the world could grasp the concept of oneness, there would be no more conflict and the world would be peaceful. By remembering this, one can be more aware, helpful and forgive one another (connectedness). The concept of human governance also carries explanation on the contribution of self-accountability and self-awareness; meaning that even if we are not accountable or answerable to something, it does not allow us to practice something beyond the values of humanity.

Human governance emphasises on the importance of consciousness, which is the state or quality of awareness, or, being aware of an external object or something within oneself. Despite the difficulty in definition, many philosophers believe that there is a broadly shared underlying intuition about what consciousness is. The dictionary meaning of the word consciousness has extended through several centuries and associated cognate meanings ranging from formal definitions to those that are more sceptical. One formal definition indicating the range of these cognate meanings is given in Webster's Third New International Dictionary stating that consciousness is "the awareness or perception of an inward psychological or spiritual fact; intuitively perceived knowledge of something in one's inner self".

Human governance can be referred to the original intention of a corporation, homing on values that should be upheld during decision making. Corporate scandals that occurred have only further endorsed the benefits of human governance. Besides, reactionary corporate governance measures were unable to impede further disgrace; it only tells us that we have nothing to lose by upholding human governance. To the accountants' fraternity with human governance in place, the essence of the true and fair principle becomes less rhetorical. Therefore, from the bigger picture, human governance can improve human well-being.

In dealing with problem-solving, human governance suggests that we should start from the root of the problem. Root cause analysis generally involves looking for reasons to explain the reasons for a problem that occurs. In most cases, there are many reasons for any given problem. Correcting the root cause is imperative as it will prevent future occurrence of the same problem and potentially many others. The practice of addressing the root cause is underpinned by the belief that problems are best solved by attempting to correct or eliminate their root causes, as opposed to merely addressing the immediate obvious symptoms (Salleh \& Ahmad, 2008). By directing corrective measures at root cause, it is hoped that the likelihood of problem recurrence will be minimised. 
However, it is recognised that complete prevention of recurrence by a single intervention is not always possible. The human governance approach suggests that the root cause of unethical behaviour is a rule-based structure founded in accounting environments including the accounting education system. To prevent or reduce unethical behaviour, it is important to understand 'what motivates people to be ethical' or 'how to make people govern them'. To answer these questions, this study argued for the need to have an alternative approach to disseminate ethics in accounting education.

If the proposal is implemented, the cooperation and support from the Ministry of Higher Education (MOHE) and educators from Malaysian Public Universities is of crucial. In order to inculcate such concept, the definition of human according to existing ethics needs to be revisited. Since the concept of human governance is a new concept that differs from the traditional structure of rule-based, this study took a step to investigate the presence of any human governance elements in existing curriculum through ethics course, which is principle based approach, as an alternative to the traditional rule-based approach.

\section{Method}

To achieve the study objective on how ethics are currently embedded in accounting education curriculum by the institution, a review on documents and webpages of the higher institutions involve in this study constituted the main data sources. To assess the relative importance that attaches higher educational institutions to business ethics, a document review on the course of ethics from the top 55 business schools across three regions of the US (19), Europe and Africa (22), as well as the AsiaPacific (14), was carried out. Top universities for Accounting \& Finance in 2016 by QS top universities (QS) were used to identify the top business schools. Since the QS ranking excludes a number of good business schools in the Asia-Pacific region, reference has been made to the ratings given by Asia Inc. (2016-2017). Additionally, not all top universities listed under QS ranking offer undergraduate accounting programme. Consequently, the best colleges U.S. News \& World Report ranking accredited by the Association to Advance Collegiate Schools of Business was also used in this study. The list is provided in the Appendix. In Malaysia context, the unit of analysis was the documentations related to four universities offering accounting programmes in Malaysia and had representatives involved in the finalisation of Hala Tuju 2 since there were no amended made in Hala Tuju 3.

This study also investigates the objectives of ethics courses offered by universities, which either to produce a framework of problem solving or to nurture students' moral characters. The percentage of credit coverage in the graduate accounting curriculum and the content involving the teaching of ethics traditional theory, any western bias, any element of human governance as the theoretical explanation was also observed. However, this study only reviewed the vision and mission of the four Malaysia universities as well as coverage of ethics course. The universities included are Universiti Kebangsaan Malaysia, University Malaya, Universiti Putra Malaysia and International Islamic University of Malaysia. The information obtained were related to curriculum structure as well as vision, mission and philosophy of each university involved. Meanwhile, descriptive analysis and qualitative technique of content analysis were used to analyse the data. 
According to Hsieh \& Shannon (2005), the current applications of content analysis involve three distinct approaches; conventional, directed and summative. These approaches are used to interpret the meaning from the content of text data and hence adhere to the naturalistic paradigm (pg. 1277). The major differences among these approaches are coding schemes, origins of codes and threat to trustworthiness. In conventional content analysis, coding categories are directly derived from the text data. With a directed approach, analysis starts with a theory or relevant findings as guidance for initial codes. A summative content analysis involves the counting and comparison of keywords or content followed by the interpretation of underlying context. This study applied summative content analysis as explained by Hsieh \& Shannon (2005). The analysis began with identifying and quantifying certain words or content in text with the purpose of understanding the contextual use of the words or content. This quantification is an attempt to not infer meaning, but rather to explore usage. Similar to this study, content analysis from this approach has been reported in studies that analysed manuscript types in a particular journal or specific content in textbooks.

\section{Analyses and Results}

Generally, most accounting degrees are accredited by a relevant professional body for accountants at the national level. For instance, UK-based accounting programme is accredited by the Association of Chartered and Certified Accountants, Institute of Financial Accountants and Chartered Institute of Management Accountants, and the American Institute of Certified Public Accountants based in the US. Studying an accredited degree allows graduates to apply to the relevant body for exemption from certain exams once they start working towards chartered accountant status.

In the US region, the length of undergraduate degree in accounting is four years. Accounting students often take a break to work in an internship position for a semester or one full year. This provides some practical experience as well as course credit available. With courses in finance, statistics, mathematics and business, the typical course load of a student can be daunting. Accounting majors are required to take 120 credits during their undergraduate career. These include the general education courses handled in the first two years of study, elective courses and accounting major courses. After undergraduate school, comes the opportunity for advanced education like a master's degree in accounting and even a CPA designation. In order to sit for the CPA exam, students need to have an additional of 30 college credits past the undergraduate degree.

\section{The way ethics is embedded in existing accounting curriculum}

As evident from Table 1 with regards to the curriculum, 53\% universities/business schools in this study favoured introducing ethics in their curriculum either as a core or elective. However, out of this number, 17 universities/business schools introduced ethics as a core subject, 8 universities/ business schools employed ethics as an elective course and only 4 universities introduced ethics as both core and elective subject. Additionally, only $28 \%(4(3+1)$ out of 14$)$ business schools/universities in Asia Pacific region introduced ethics as a core subject compared to 53\% (10 (9+1)) in America, 32\% (7+0 universities out of 22) in European and African region. There were eight business schools (2 in the Americas and 4 Asia-Pacific school and 2 in Europe) that have made efforts to integrate ethics as an 
elective subject in their curriculum. Meanwhile, there were four business schools, 1 US-based and 3 in Asia-Pacific, which took the initiative of giving a both core and elective orientation to their ethics course. At most, universities spend less than $8 \%$ on standalone ethics course from their total credit hours. University of Cape Town, South Africa spend 60 credit hours (credit points) as well as University of Scranton, US ( 9 credit hours) on 3 stand-alone subjects of ethics. However, the total credit of accounting programme in University of Cape Town, South Africa, was not available in their official website. In Malaysia (Table 2), only International Islamic University Malaysia do not have stand-alone ethics subject in their accounting curriculum. Other universities have one standalone subject of ethics as a core subject while only Universiti Sains Malaysia has one elective subject of ethics.

Table 1: International Universities

\begin{tabular}{|c|c|c|c|c|c|}
\hline Region & $\begin{array}{l}\text { US } \\
\text { region } \\
(19)\end{array}$ & $\begin{array}{l}\text { Asia Pacific } \\
\text { Region (14) }\end{array}$ & $\begin{array}{l}\text { Europe \& } \\
\text { African } \\
\text { region } \\
(22)\end{array}$ & Total & Percentage \\
\hline \multicolumn{6}{|l|}{$\begin{array}{l}\text { Length (year) of } \\
\text { study }\end{array}$} \\
\hline 4 years & 19 & 6 & 6 & 31 & $56 \%$ \\
\hline 3 years & 0 & 6 & 16 & 22 & $40 \%$ \\
\hline $\begin{array}{l}\text { Information not } \\
\text { available }\end{array}$ & 0 & 2 & 0 & 2 & $4 \%$ \\
\hline Total & 19 & 14 & 22 & 55 & $100 \%$ \\
\hline \multicolumn{6}{|l|}{$\begin{array}{l}\text { Ethics in } \\
\text { curriculum }\end{array}$} \\
\hline Core only & 9 & 1 & 7 & 17 & $31 \%$ \\
\hline Elective only & 2 & 4 & 2 & 8 & $15 \%$ \\
\hline $\begin{array}{l}\text { Both Core \& } \\
\text { elective }\end{array}$ & 1 & 3 & 0 & 4 & $7 \%$ \\
\hline None & 5 & 5 & 13 & 23 & $42 \%$ \\
\hline $\begin{array}{l}\text { Information Not } \\
\text { available }\end{array}$ & 2 & 1 & 0 & 3 & $5 \%$ \\
\hline Total & 19 & 14 & 22 & 55 & $100 \%$ \\
\hline
\end{tabular}


INTERNATIONAL JOURNAL OF ACADEMIC RESEARCH IN BUSINESS AND SOCIAL SCIENCES Vol. 8, No. 12, Dec, 2018, E-ISSN: 2222-6990 @ 2018 HRMARS

Table 2: National Universities

\begin{tabular}{|c|c|c|c|c|c|c|}
\hline $\begin{array}{l}\text { National } \\
\text { Universities }\end{array}$ & $\begin{array}{l}\text { International } \\
\text { Islamic } \\
\text { University } \\
\text { Malaysia } \\
\text { (IIUM) }\end{array}$ & $\begin{array}{l}\text { National } \\
\text { University } \\
\text { of } \\
\text { Malaysia } \\
\text { (UKM) }\end{array}$ & $\begin{array}{l}\text { University } \\
\text { Malaya }\end{array}$ & $\begin{array}{l}\text { Universiti } \\
\text { Teknologi } \\
\text { Mara }\end{array}$ & $\begin{array}{l}\text { Universiti } \\
\text { Putra } \\
\text { Malaysia }\end{array}$ & $\begin{array}{l}\text { Universiti } \\
\text { Sains } \\
\text { Malaysia }\end{array}$ \\
\hline \multicolumn{7}{|l|}{$\begin{array}{l}\text { Length } \\
\text { (year) of } \\
\text { study }\end{array}$} \\
\hline 4 years & V & V & V & $\mathrm{V}$ & V & V \\
\hline \multicolumn{7}{|l|}{3 years } \\
\hline \multicolumn{7}{|l|}{$\begin{array}{l}\text { Ethics in } \\
\text { curriculum }\end{array}$} \\
\hline Core only & & V & $\mathrm{V}$ & $\sqrt{ }$ & v & \\
\hline \multicolumn{7}{|l|}{$\begin{array}{c}\text { Elective } \\
\text { only }\end{array}$} \\
\hline $\begin{array}{l}\text { Both Core \& } \\
\text { elective }\end{array}$ & & & & & & V \\
\hline
\end{tabular}

\section{Content of ethic course offered by universities}

To answer the second question, which is "Is there any human elements (affective education) embedded in ethics course offered by universities?" Names and codes of ethics as well as course description of ethics subject are shown in Table 3. Content analysis was used to analyse the above dimensions based on the expected themes to derive the findings through the next section of the study. Due to the non-availability of course outline in the website, only 28 course syllabuses were collected from the universities listed in this study. A few dimensions were reviewed and examined to investigate and explore the ethics themes by content analysis methodology in four dimensions existed within the outlines. Table 3 illustrates the brief content of ethics course in accounting curriculum offered by universities involved in this study. It was divided into 4 regions, which are US/American region (11 universities/ business schools), Asia Pacific region ( 9 universities), European and African region ( 8 universities). From the course description, this study examined 12 outlines to explore the nature of ethics description themes of either contemporary (coded as A) or the availability of human governance element (coded as B). In general, the current ethics and corporate governance syllabi are included in the following themes on Panel A, Contemporary ethics; (i) Corporate governance, (ii) Codes of ethics and professional conduct, (iii) Ethical issues, (iv) Ethical dilemma. This study tries to investigate any supplementary contents coded as $B$, which represents human governance elements.

Based on Table 3, 14 universities (50\%) have corporate governance followed by 8 universities (29\%) with ethical dilemma, ethical issues, Codes of ethics and professional conduct and theory of ethics. Meanwhile, 4 universities (14\%) have CSR in their syllabus. Other issues discussed in ethics course 
were moral judgment, stewardship and accountability to shareholders. In human governance theme (in panel B), only more than 7\% (2 universities) have discussed the issues of interconnectedness, worldview, natural law and obligation to God in current syllabi. It was also noticed that the topic of corporate governance was mostly discussed in Asia Pacific and European African region, while the American region put more emphasis on ethical reasoning as in Table 3. In addition, human governance elements were discussed in one university in US region and 2 universities at Asia Pacific region.

Table 3: Content of Ethics syllabi

\begin{tabular}{|c|c|c|c|c|c|c|}
\hline Panel & Contents & $\begin{array}{l}\text { US } \\
\text { region } \\
\text { (11) }\end{array}$ & $\begin{array}{l}\text { Asia } \\
\text { Pacific } \\
\text { Region } \\
\text { (9) }\end{array}$ & $\begin{array}{l}\text { Europe \& } \\
\text { African region } \\
\text { (8) }\end{array}$ & Total (28) & Percentage \\
\hline$A$ & $\begin{array}{l}\text { Ethical } \\
\text { dilemma/ } \\
\text { ethical } \\
\text { reasoning }\end{array}$ & 6 & 1 & 1 & 8 & $28.6 \%$ \\
\hline A & Ethical issue & 3 & 3 & 2 & 8 & $28.6 \%$ \\
\hline$A$ & $\begin{array}{l}\text { Corporate } \\
\text { governance }\end{array}$ & 4 & 5 & 5 & 14 & $50.0 \%$ \\
\hline$A$ & $\begin{array}{l}\text { Code of Ethics/ } \\
\text { professional } \\
\text { conduct }\end{array}$ & 3 & 2 & 3 & 8 & $28.6 \%$ \\
\hline$A$ & $\begin{array}{l}\text { Theory of } \\
\text { ethics }\end{array}$ & 3 & 3 & 2 & 8 & $28.6 \%$ \\
\hline$A$ & $\begin{array}{l}\text { Moral } \\
\text { judgement }\end{array}$ & 2 & 0 & 0 & 2 & $7.1 \%$ \\
\hline$A$ & $\begin{array}{l}\text { Stewardship/ac } \\
\text { countability }\end{array}$ & 0 & 2 & 0 & 2 & $7.1 \%$ \\
\hline$A$ & CSR & 0 & 3 & 1 & 4 & $14.3 \%$ \\
\hline B & $\begin{array}{l}\text { Interconnected } \\
\text { ness }\end{array}$ & 0 & 2 & 0 & 2 & $7.1 \%$ \\
\hline $\mathrm{B}$ & Worldview & 1 & 0 & 0 & 1 & $3.6 \%$ \\
\hline $\mathrm{B}$ & Natural law & 1 & 0 & 0 & 1 & $3.6 \%$ \\
\hline B & $\begin{array}{l}\text { Obligation to } \\
\text { God }\end{array}$ & 1 & 0 & 0 & 1 & $3.6 \%$ \\
\hline
\end{tabular}

In Malaysia, the Reassessment Report on Accounting Programme at Public Universities of Malaysia 2006 (Hala Tuju 2) showed that the framework of ethics education in accounting education curriculum should be premised on theories of ethics, and the international code and rules. Since this international code and rules are sometimes not applicable to Malaysia, certain amendments have 
INTERNATIONAL JOURNAL OF ACADEMIC RESEARCH IN BUSINESS AND SOCIAL SCIENCES Vol. 8, No. 12, Dec, 2018, E-ISSN: 2222-6990 C 2018 HRMARS

been made. The Malaysia's framework of codes and rules such as code of ethics and corporate governance as well as other local financial rules were also included in the ethics education framework. The findings in course description implied very small existence of ethics theories (Egoism, Utilitarianism, Virtue and Deontology) to expand the undergraduate students' perception on the critical thinking of ethical decision making while facing ethical dilemmas. However, the element of human governance has been embedded in ethics and corporate governance in university Putra Malaysia since 2015.

\section{Embedded ethics through official pronouncements}

To answer the third question in the first objective, which is "how Malaysia Public Universities embedded ethics through their official pronouncement?" the mission and vision of four public universities including their faculty and department that offer undergraduate programmes were examined and reviewed. The result for the third study objective is represented in Table 4.

Table 4- Ethics through Malaysian Universities' Official Pronouncements

\begin{tabular}{|c|c|c|c|c|c|}
\hline $\begin{array}{l}\text { Official } \\
\text { Pronouncements } \\
\text { (internal } \\
\text { enforcement) }\end{array}$ & $\begin{array}{l}\text { National } \\
\text { Universities }\end{array}$ & $\begin{array}{l}\text { International } \\
\text { Islamic } \\
\text { University } \\
\text { Malaysia } \\
\text { (IIUM) }\end{array}$ & $\begin{array}{l}\text { National } \\
\text { University } \\
\text { of } \\
\text { Malaysia } \\
\text { (UKM) }\end{array}$ & $\begin{array}{l}\text { University } \\
\text { Malaya }\end{array}$ & $\begin{array}{l}\text { Universiti } \\
\text { Putra } \\
\text { Malaysia }\end{array}$ \\
\hline \multirow[b]{2}{*}{ Vision } & Conventional & & & $\sqrt{ }$ & $\mathrm{V}$ \\
\hline & $\begin{array}{l}\text { Non- } \\
\text { conventional }\end{array}$ & V & V & & \\
\hline \multirow[b]{2}{*}{ Mission } & Conventional & & & V & V \\
\hline & $\begin{array}{l}\text { Non- } \\
\text { conventional }\end{array}$ & $\sqrt{ }$ & v & & \\
\hline \multirow[b]{2}{*}{ Faculty mission } & Conventional & & & $\sqrt{ }$ & $\sqrt{ }$ \\
\hline & $\begin{array}{l}\text { Non- } \\
\text { conventional }\end{array}$ & v & v & & \\
\hline \multirow{2}{*}{$\begin{array}{c}\text { Objective of } \\
\text { Accounting } \\
\text { program }\end{array}$} & Conventional & & & V & V \\
\hline & $\begin{array}{l}\text { Non- } \\
\text { conventional }\end{array}$ & v & v & & \\
\hline
\end{tabular}

The vision and mission statements of each university contain unequivocal references to certain notions that could be associated with their identity. The vision and mission statements discussed were essentially formulated within the context of each university as a whole. In addition to these pronouncements, a review was also carried out on similar statements made by the faculty where the programme of accounting was conducted. This thought is useful in identifying the synchronisation of vision and mission of university, faculty and objectives of the programme. The vision and mission will also show the commitment of universities towards embedding ethics at the university level. 
The vision or pronouncement made at university level can be divided into two categories; (1) conventional based and (2) non-conventional based. The first category was viewed as "materialistic" pronouncement since the vision is more excessively concerned with physical comfort or the acquisition of wealth and material possessions rather than spiritual, intellectual, or cultural values. On the other hand, the second category of pronouncement showed the concern on spiritual, intellectual or cultural values.

The pronouncements appeared such as 'To be an internationally renowned institution of higher learning in research, innovation, publication and teaching' (University of Malaya) and 'To become a university of international repute' (Universiti Putra Malaysia) focused on the challenges in higher education industry. These universities have not made any reference to any specific values or ideals in the vision. These universities also seemed to indicate an intention to contribute to the progress of human civilisation by means of advancement in knowledge.

The first category of universities' mission statements appeared to stipulate several main objectives that need to be achieved. These objectives, as with the case of the university's vision statement, did not seem to indicate universities' explicit commitment to a specific set of values. The prime objective of these universities, for instance, seemed to reflect a belief in the importance of knowledge and skills to produce competitive products (students), hence the promotion of a material world view.

The goal within the first category also appeared to reflect some degree of emphasis on societal responsibilities. The mention made from 'To intensify community involvement for the generation and sharing of knowledge' and 'Communicate effectively with other professionals and the community, and project a coherent vision of social responsibilities' did not seem to specifically indicate its commitment to or a sense of direction in fostering ethical development of its students spiritually. Some universities, however, mentioned their ethical values in a separate pronouncement. Among the values announced are transparency, collegiality, innovation, accountability, merit, integrity, respect, academic freedom, open-mindedness, professionalism, meritocracy, teamwork, creativity, social responsibility, excellence, diversity and sustainability

The statements made by faculty at the universities involved in this study appeared to reflect the university's emphasis on advancements in knowledge. For the faculty, however, such advancements are expressed within the context of business and management to meet the need of employability. As with the pronouncements made at the university level, the statements made by faculty in the universities at the first category, in the researcher's view, did not seem to indicate a commitment in developing the students' moral characters. Instead, the pronouncements were focused on the challenges in business environment and the ways in which education at the faculty would enable the students to face those challenges. While such educational outcome is common to many business and management faculties, this, to a certain extent, would have also implied faculty's endorsement of competitiveness that in turn may well be associated with university's emphasis on the 'world class' reputation institution as explicitly stated in its vision statement. 
For the second category, vision statements from most universities listed out the aims that are meant to distinguish the university from other institutions. Their vision statements were based on either culture or religion (Islam). The promotion of the sovereignty of Malay language and internationalisation of knowledge rooted in the national culture, as stipulated in UKM's vision, potentially reflects the university's endorsement of patriotism spirit.

IIUM on the other hand stated its vision as inspired by the world view of Tawhid (concept of monotheism or asserting oneness) and the Islamic philosophy of the unity of knowledge as well as its concept of holistic education, which aims at becoming a "leading international centre of educational excellence that seeks to restore the dynamic and progressive role of the Muslim Ummah in all branches of knowledge for the benefit of all mankind' essentially concerned with the pursuit of Islamic causes on the matter of knowledge. Such aims include the restoration of intellectual vigour in the Muslim Ummah, integration of Islamic values into all disciplines of knowledge and the reestablishment of the place of Muslim Ummah at the forefront of knowledge to improve the quality of human life. Such beliefs may thus be contrasted with the educational mission in the first category. The values were embedded in vision or mission statements where the concept of monotheism (Tawhid), the quality of faith (iman), knowledge ( ilm), good character (akhlaq) and Islamic moralspiritual values were mentioned. Table 4 also depicts the vision, mission and values pronouncement (if any) for the first and second categories, respectively.

Each faculty's statements in the second category of vision and mission are also presented in Table 4. For the Kulliyyah of Economics and Management Sciences at IIUM, there were three major elements that could be associated with the pronouncements made at the university level. First, the faculty aspires to excel as a centre of education particularly in the areas of economics, accounting and business. Second, the faculty attaches itself to the idea of integrating religion based values and ethics into each of the three disciplines of knowledge. Third, in the first objective stated in its mission, the faculty has made specific reference to Islamic values and ethics in respect to the moral qualities from the integration of Islamic ideals into all branches of knowledge. The faculty may be seen to have expressed a commitment to ethical development of accounting students at undergraduate level through the use of terms that may be associated with Islam that such development shall have a religious and spiritual bearing. Specific mentions were also made of other qualities that the Faculty of Economics and Management, UKM seeks to instil into the students including professional competence and the values of care and compassion.

Overall, based on a review of pronouncements made by the university and the faculty, some observations may be offered regarding values within the context of education in these particular universities. First, the first category of university seemed to affix itself to the purpose of university education in a more conventional sense that is the pursuit of academic excellence. Second, while these particular universities did not appear to make an explicit commitment to a certain set of values, the objectives found within its mission statement could be argued to imply an emphasis on certain matters such as the materialist worldview, social responsibility, competitiveness and the support for diversity (research, teaching and publication). Third, these universities have not made any indication 
INTERNATIONAL JOURNAL OF ACADEMIC RESEARCH IN BUSINESS AND SOCIAL SCIENCES

Vol. 8, No. 12, Dec, 2018, E-ISSN: 2222-6990 @ 2018 HRMARS

of the importance of spiritual elements in their educational context. Fourth, the pronouncements made by the universities and faculties did not explicitly indicate a commitment to develop the students' moral characters.

In the view of this study, the official pronouncements made at the faculty and objective of the programme were synchronised with university's vision and mission. However, not all public universities encourage embedding ethics in into their vision and mission. Consequently, the vision and mission of the faculty and the department of accounting will be parallel with those of university. Nevertheless, some of the universities signified the endorsement of values at separate statements other than vision and mission. It is highly likely, therefore, that these are the values that the university subscribed to and emphasised within its community.

Results showed that more than half (53\%) of the universities selected in this study took an initiative to embed ethics course in their accounting curriculum by offering a stand-alone ethics course either as a core course, elective course or the combination of both. Furthermore, the absence of explicit embedding of ethics into the curriculum was also apparent when examining each institution's mission and vision statements of the four local public universities, faculty and objectives of accounting programme.

\section{Discussion}

This study found that despite the encouragement by IES 4, not all universities involved in this study either internationally or locally have one separate core or optional course of Business Ethics offered in business faculty as well as accounting department. In some universities, there is no stand-alone ethic course offered out of accounting department such as marketing, economy, businessadministration, management information system. It could be described as an outlier attempt to enforce ethics education into business faculty multi-departments catalogue, and mirror a stand-alone ethics course method. In addition, the decline may be encouraged by the flexibility of certain standards such as the Association to Advance Collegiate Schools of Business (AACSB) that require fewer stand-alone ethics courses offered started from 2007 (Blanthorne, Kovar, \& Fisher, 2007). In line with this, Thompson (2013) and O'Brien (2013) suggest that more integration in business ethics curriculum is needed. To increase an embedded ethics in curriculum, enforcement from accreditation bodies (AACSB, MIA) is crucial. As Vidaver-Cohen (2004) demonstrated that the convergence of formal (accreditation bodies, accountancy boards, and deans) and informal authorities (enthusiastic faculty and students) is required for a successful curriculum revision to incorporate ethics.

In general, the current ethics and corporate governance syllabi include the following themes by ranking (1) corporate governance (2) Ethical dilemma, Ethical issue, Codes of ethics and Professional conduct theory of ethics and (3) CSR. Issues discussing moral judgment, stewardship and accountability to shareholders are very rare in ethics course. A common practice reported in the literature is the teaching ethics in concert with a professional code of conduct or ethics. Accounting majors are likely required to work within a code structure using one as a motivation for the curriculum as a reasonable notion (Roybark, 2008). Due to the increasing number of corporate accounting 
INTERNATIONAL JOURNAL OF ACADEMIC RESEARCH IN BUSINESS AND SOCIAL SCIENCES Vol. 8, No. 12, Dec, 2018, E-ISSN: 2222-6990 @ 2018 HRMARS

scandals, professional accounting bodies worldwide have introduced new or revised existing codes and rules. Accordingly, IFAC through its International Accounting Education Standard Board (IAESB) developed the accounting education framework parallel to this rule-based structure.

The Malaysian framework of codes and rules such as codes of ethics and corporate governance and other local financial rules were also included in the ethics education framework. The findings in course description implies very small existence of Ethics Theories (Egoism, Utilitarianism, Virtue, Deontology) to expand the undergraduate students' perception in the critical thinking of ethical decision making while facing ethical dilemmas. According to (Anzeh \& Abed, 2015), these theories assist the students to shape a significant cognitive background to understand more ethical concepts, nature, psychological, as well as behavioural and social aspects of the human ethical conduct rather than to believe that the ethics material is districted in some topics that need more digestive academic processing to be tackled such as the standardised moulds of applied ethics, which is sufficient to be delivered to accounting students. For example, the Ethical Code of Professional Conduct as a matter integrated within auditing curriculum focused basically on characteristics as a requirement for a qualified person. This result reveals that current ethics syllabus implement rule-based education. As mentioned earlier in literature, fixed legalistic mind-set is one of inadequacies of ethics in accounting education due the current practice of implementing rule-based education. The insufficiency of code of ethics as a legal compliance mechanism in influencing ethical behaviour has been proven in various studies (Kapteinand Schwartz, 2008; Helin and Sandstro"m, 2007; Healy and Iles, 2002; Mohammad et al. 2002; Marnburg, 2000; Clark and Leonard 1998; Brooks, 1989). In addition, Arjoon (2005) claimed that legal compliance mechanisms are insufficient and may not be addressing the real and fundamental issues that inspire ethical behaviour.

The result also showed that the goal of ethics education is not moral conversion, but rather to help well-intentioned students in developing the skills necessary to identify and resolve ethical dilemmas. Armstrong (1993) argued that the positive effects of ethics education are on the quality of students' moral development. The current practice of rule-based approach in ethics accounting education with emphasis on compliance with the laws needs to be revisited or revised. Ryack, Mastilak, Hodgdon \& Allen (2015) suggested that where possible, accounting educators may wish to teach principles based accounting prior to rules based accounting to mitigate potential anchoring by students and its effect on their accounting judgement. Maybe the concept of human governance, which is the principle based approach that can be embedded in ethics course as an alternative to the traditional rule-based approach. In the current practice, the content of human governance significantly appeared in current syllabi of ethics at University of Scranton, the US and two universities from Singapore as well as at Universiti Putra Malaysia.

In investigate the official pronouncement (vision and mission) of four public universities in Malaysia, not all public universities were selected in this study encouraging embedding ethics through their vision and mission. Consequently, the vision and mission of the faculty and the department of accounting are parallel with university. According to Apostolou, Dull and Schleifer (2013), to incorporate ethics in accounting curriculum, motivation from external and internal pressure is 
needed. Since the need of ethics has been required by accreditation bodies such as MIA and AACSB, it should be expressed as one of the missions of the universities to show their commitment towards developing ethical behaviour among students in corporate level. Business school deans and renowned business ethicists at prominent universities joined the call for action to maintain the AACSB accreditation by encouragement in embedded ethics since 2004 as cited "The time has come for business schools to renew and revitalise their commitment to the centrality of ethical responsibility at the individual and corporate levels in preparing business leaders for the $21^{\text {st }}$ century" (AACSB International, 2004, pg. 9). However, result of this study presented that not all universities responded to the suggestion.

\section{Conclusion and Suggestions}

The first objective of this study refers to the degree to which ethics is incorporated or embedded in the accounting curriculum. The document review done appeared to show that only a half proportion of accounting programmes have significant ethical content. To increase human values and ethics (as a core of professionalism), policy makers, such as IFAC, MIA and Association to Advance Collegiate Schools of Business (AACSB), should enforce the instillation of ethics and human values in the accounting curriculum.

This study had also found that the issues of moral judgment, stewardship and accountability to shareholders are rarely discussed in ethics course as well as human governance principles such as oneness, interconnectedness and consciousness. To increase a human element in the accounting ethics education, to shift the rule based stratagem of corporate governance to principle based, to build an ethical character and to develop of spiritual side of human being, the objectives and contents of the ethics course should be revisited and reviewed.

The vision and mission of the local universities involved in this study was not encouraging when it comes to the instillation of ethics. Based on the finding, this study concluded that despite of encouragement by IES 4, Hala Tuju 2 and 3, not all universities have a separate core or an optional course of Business Ethics offered at their business faculty or even at their accounting department. To increase internal pressure in incorporating ethics in the accounting curriculum, ethics and human values should also be expressed within the vision and mission of the universities to show their commitment towards developing ethical behaviour among students.

The finding of this study contributes to a new way for educators to teach an ethics subject in the accounting curriculum by introducing a potential areas which is human governance, to enhance moral and character building (spiritual part) of students in the current accounting programmes. Thus, policy makers should provide a platform to promote the human governance principle based approach in developing a holistic accounting education curriculum as the external and internal pressure. This study is an example of the summative content analysis as explained by Hsieh \& Shannon (2005), which is a limited method use in literature. 
INTERNATIONAL JOURNAL OF ACADEMIC RESEARCH IN BUSINESS AND SOCIAL SCIENCES

Vol. 8, No. 12, Dec, 2018, E-ISSN: 2222-6990 @ 2018 HRMARS

\section{References}

AACSB. (2004). Report of the Ethics Education Task Force. Retrieved September 24, 2009, from grme.org: http://www.gfme.org/issues/pdfs/EthicsEducation.pdf

AACSB. (2006). AACSB Eligibility Procedures and Accreditation Standards for Business Accreditation. Retrieved September 21, 2009, from AACSB:

http://www.aacsb.edu/accreditation/standards.asp.

Amernic, J., \& Craig, R. (2004). Reform of the accounting education in the post-enron era: moving accounting 'out of the shadows'. Abacus, 342-78.

Anzeh, B. A., \& Abed, S. (2015). The Extent of Accounting Ethics Education for Bachelor Students in Jordanian Universities. Journal of Management Research, Vol. 7, No. 2, 121-143.

Apostolou, B., Dull, R., \& Schleifer, L. F. (2013). A framework for the pedogogy of accounting ethics. Accounting Education : an international journal , Vol. 22, No. 1, 1-17.

Arjoon, S. (2005). Corporate Governance: An Ethical Perspective. Journal of Business Ethics, 61, 343352.

Armstrong, M. B. (1993). Ethics and professionalism in accounting education: A sample course. Journal ofAccounting Education 11 (1), 77-92.

Blanthorne, C., Kovar, S. E., \& Fisher, D. G. (2007). Accounting Educators' Opinions about Ethics in the Curriculum: An Extensive View. Issues in Accounting Education. vol 22. No. 3, 355-390.

Boyce, G. (2008). The social relevance of ethics education in global(ising) era: From invidual dilemmas to systemic crises. Critical Perspectives on Accounting 19, 255-290.

Brooks, L. (1989). Corporate Codes of Ethic. Journal of Business Ethics, 8, 117-29.

Clark, M., \& Leonard, S. (1998). Can Corporate Codes of Ethics Influence Behavior? Journal of Business Ethics, 17, 619-30.

Cohen, J. R., \& Pant, L. W. (1989). Accounting Educators' Perceptions of Ethics in the Curriculum. Issues in Accounting Education, vol. 4, no. 1, 70-81.

Das, M. (2015, October 29). Need, Relevancy and Impact of Ethics Education on Accounting Profession. Xavier Institute of Management, Bhubaneswar, India.

Dellaportas, S., Gibson, K., Alagiah, R., Hutchinson, M., Leung, P., \& Van, H. D. (2005). Ethics, governance \& accountability. Milton: John Wiley \& Sons Australia, Ltd.

Dellaportas, S., Kanapathippillah, S., Khan, A., \& Leung, P. (2014). Ethics Education in the Australian Accounting Curriculum: A Longitudinal Study Examining Barriers and Enablers. Accounting Education : An International Journal, 362-382.

Fisher, D. G., \& Swanson, D. L. (2005). A Call to Strengthen Proposed NASBA Ethics Requirements: a Three Step Formula. Compliance \& Ethics, 2(3), 36-38.

Fisher, D. G., Swanson, D. L., \& Schmidt, J. (2011). Accounting Education Lags CPE Ethics Requirements: Implications for the Profession and a Call to Action. Accounting Education: an International Journal, vol. 16, No. 4, 345-365.

Gandz, J., \& Hayes, N. (1988). Teaching business ethics. Journal of Business Ethics, 7, pp. 657-669.

Geary, W. T., \& Sims, R. R. (1994). Can ethics be learned? Accounting education 3 (1), 3-18.

Ghaffari, F., Kyriacou, O., \& Brennan, R. (2008). Exploring the Implementation of Ethics in U.K. Accounting Programs. Issues in Accounting Education, vol.23, no. 2, 183-198. 
INTERNATIONAL JOURNAL OF ACADEMIC RESEARCH IN BUSINESS AND SOCIAL SCIENCES

Vol. 8, No. 12, Dec, 2018, E-ISSN: 2222-6990 @ 2018 HRMARS

Glover, H., \& Aono, J. (1995). Changing the Model for Prevention and Detection of Fraud. Managerial Auditing Journal, 10:5, 3-9.

Gray, R. H., Owen, D., \& Maunders, K. T. (1987). Corporate Social Reporting : Accounting and Accountability. Hemel Hempstead: Prentice Hall.

Gray, R., Bebbington, J., \& McPhail, K. (1994). Teaching Ethics in Accounting and the Ethics of Accounting Teaching: Educating for Immorality and a Possible Case for Social and Environmental Accounting Education. Accounting Education 3 (1), 51-75.

Haberman, L. (2003). Special Report: Sarbanes-Oxley Act Tops NASBA Meeting Agenda. Journal of Accounting, 22-23.

Healy, M., \& Iles, J. (2002). The Establishment and Enforcement of Codes. Journal of Business Ethics, 117-124.

Helin, S., \& Sandstro"m, J. (2007). An Inquiry into the Study of Corporate Codes of Ethics. Journal of Business Ethics 75, 253-271.

High Level Group on the Modernisation of Higher Education. (2013). Improving the quality of teaching and learning in Europe's higher education institutions. Luxembourg: Publications Office of the European Union.

Hosmer, L. T. (1988). Adding ethics to the business curriculum. Business Horizons, 31(4), pp. 9-15.

Hsieh, H.-F., \& Shannon, S. E. (2005). Three Approaches to Qualitative Content Analysis. Qualitative Health Research, Vol. 15 No. 9, 1277-1288.

IFAC. (2006). IES 4 Professional Values, Ethics and Attitudes. Retrieved August 24, 2008, from IFAC: http://www.ifac.org

IFAC. (2008). 2008 IFAC Global Leadership Survey on the Accountancy Profession -Summary of results. IFAC.

IFAC. (2008). Introduction to International Education Standards. Retrieved September 25, 2009, from IFAC: http://www.ifac.org.

International Islamic University of Malaysia. (2010). Retrieved May 12, 2014, from The IIUM Vision: http://www.iium.edu.my/about-iium/iium-vision

Jackling, B., Leung, P., \& Dellaportas, S. (2007). Professional accounting bodies' perceptions of ethical issues,causes of ethical failure and ethics education. Managerial Auditing Journal, 928-944.

Jaijairam, P. (2018). Ethics in Accounting . Journal of Finance and Accountancy, 1-13.

Kaptein, M., \& Schwartz, M. S. (2008). The Effectiveness of Business Codes: A Critical Examination of Existing Studies and the Development of an Integrated Research Model. Journal of Business Ethics 77, 111-127.

Kerr, D. S., \& Smith, L. M. (1995). Importance of and approaches to incorporating ethics into the accounting classroom. Journal of Business Ethics, 14, pp. 987-995.

Lehman, C. (1988). Accounting Ethics: Surviving Survival of the Fittest. In M.Neimark, Advances in Public Interest in Accounting Vol. 2 (pp. 71-82.). Connecticut, USA: Jai Press.

Loeb, S. (1988). Teaching students accounting ethics: Some crucial issues. Issues in Accounting Education 3 (Fall), 316-329.

Low, M., Davey, H., \& Hooper, K. (2008). Accounting scandals, ethical dilemmas and educational challenges. Critical Perspectives on Accounting 19, 222-254. 
INTERNATIONAL JOURNAL OF ACADEMIC RESEARCH IN BUSINESS AND SOCIAL SCIENCES

Vol. 8, No. 12, Dec, 2018, E-ISSN: 2222-6990 @ 2018 HRMARS

Marnburg, E. (2000). The Behavioral Effects of Corporate Ethical Codes: Empirical Findings and Discussion. Business Ethics: A European Review, 9, 200-10.

McDonald, G. M., \& Donleavy, G. D. (1995). Objective to the Teaching of Business Ethics. Journal of Business Ethics 14(10), 839-853.

McPhail, K. (2001). The Other Objective of Ethics Education: Re-humanising the Accounting Profession- A Study of Ethics Education in Law, Engineering, Medicine and Accountancy. Journal of Business Ethics, 279-298.

Ministry of Higher Education, Malaysia. (2006). Reassessment Report on Accounting Programme at Public Universities in Malaysia 2006. Shah Alam: Pusat Penerbitan Universiti (UPENA), Universiti Teknologi MARA.

Ministry of Higher Education, Malaysia. (2014). Reassessment Report on Accounting Programme at Public Universities in Malaysia 2014 (Hala Tuju 3). Pusat Penerbitan Universiti (UPENA), Universiti Teknologi MARA: Shah Alam.

Mohammad, A., Maisarah, M., \& Ainun, A. (2002). Ethics and the Accounting Profession in Malaysia. The Asian Academic Accounting Association Conference. Nagoya Japan.

Oddo, A. R. (1997). A framework for teaching business ethics. Journal of Business Ethics, 16, pp. 293-297.

Piper, T. R., Gentile, M. C., \& Parks, S. D. (1993). Can ,Ethics be Taught? Perspectives, Challenges, and Approaches at Harvard Business School . Harvard Business School.

Power, M. (1991). Educating Accountants: Towards a Critical Ethnography. Accounting, Organizations and Society (16), 333-53.

Roybark, H. M. ( 2008). Educational interventions for teaching the new auditor independence rules. Journal of Accounting Education, 26(1): 1-29.

Ryack, K. N., Mastilak, M. C., Hodgdon, C. D., \& Allen, J. S. (2015). Concept-Based Education in RulesBased World: A Challenge for Accounting Educators. Issues in Accounting Education, 251.

Salleh, A., \& Ahmad, A. (2008). Human Governance. Petaling Jaya: MPH Publishing.

Salleh, A., \& Ahmad, A. (2009). Re-actualizing the Leadership of Professional Accountants in Business:The New Sciences and Human Governance Way. Kuala Lumpur: MIA.

Salleh, A., \& Ahmad, A. (2010). Human Governance: Bringing the Meaning of Integrity in life of Professional Accountants. Malaysia: Malaysia Institute of Accountant (MIA).

Salleh, A., \& Ahmad, A. (2012). A scientific worldview of accounting ethics and governance education: The right footing of International Education Standard 4. Asian Academy of Management Journal, 131-149.

Sikka, P., Haslam, C., Kyriacou, O., \& Agrizzi, D. (2007). Professionalizing claims and the state of UK professional accounting education: some evidence. Accounting Education: an International Journal, 3-21.

Swanson, D. L. ( 2011). Got Ethics: Toward Assessing Business Ethics Education, Edited by: Swanson, D. L. and Fisher, D. G. Greenwich, CT: IAP Information Age Publishing.

The Straits Times. (2018, August 23). Malaysian Institute of Accountants probing KPMG and Deloitte's handling of 1 MDB books. Retrieved October 15, 2018, from The Straits Times: https://www.straitstimes.com/asia/se-asia/malaysian-institute-of-accountants-probingkpmg-and-deloittes-handling-of-1mdb-books 
Tweedie, D., Dyball, M. C., Hazelton, J., \& Wright, S. (2013). Teaching global ethical standards: a case and strategy for broadening the accounting curriculum . Journal of Business Ethics, 115, pp. 1-15.

Universiti Kebangsaan Malaysia. (2010). Retrieved May 12, 2014, from Motto, Vission, Mission \& Philosophy: http://www.upm.edu.my/v6/motto-vision-mission-philosophy/

Universiti Putra Malaysia . (2010). Retrieved May 12, 2014, from visi/misi/matlamatkami/dasar kualiti: http://www.upm.edu.my/tentang_kami/visimisimatlamat

University of Malaya. (2010). Retrieved May 12, 2014, from Our Vision \& Mission: http://www.um.edu.my/about-um/vision-mission

Wylie, C., \& Wardle, S. (2017, September 29). Tesco bosses accused of 'cooking the books' as fraud trial begins. Retrieved October 15, 2018, from Independent News: https://www.independent.co.uk/news/business/news/tesco-fraud-trial-bosses-accusedcooking-the-books-accounting-scandal-chris-bush-carl-rogberg-john-a7974056.html 
INTERNATIONAL JOURNAL OF ACADEMIC RESEARCH IN BUSINESS AND SOCIAL SCIENCES Vol. 8, No. 12, Dec, 2018, E-ISSN: 2222-6990 C 2018 HRMARS

\section{Appendix}

List of international universities/ business schools in this study

\begin{tabular}{|c|c|c|}
\hline & & $\begin{array}{l}\text { American Region (19 selected universities) } \\
\text { Selected University }\end{array}$ \\
\hline & Country & \\
\hline 1 & US & University of Pennsylvania: Wharton \\
\hline 2 & US & University of Illinois--Urbana-Champaign \\
\hline 3 & US & Brigham Young University \\
\hline 4 & US & University of Southern California \\
\hline 5 & Canada & University of Toronto \\
\hline 6 & US & New York University: Stern \\
\hline 7 & US & $\begin{array}{l}\text { Indiana University of Bloomington } \\
\text { Kelley School of Business }\end{array}$ \\
\hline 8 & US & St. Joseph's University \\
\hline 9 & US & $\begin{array}{l}\text { Ohio State University } \\
\text { Fisher College of Business }\end{array}$ \\
\hline 10 & US & Arizona State University \\
\hline 11 & Canada & University of Ottawa \\
\hline 12 & US & Layola University Maryland \\
\hline 13 & US & The university of Scranton, A Jesuit University \\
\hline 14 & US & $\begin{array}{l}\text { University of Minnesota } \\
\text { Carlson School of Management }\end{array}$ \\
\hline 15 & US & University of North Texas \\
\hline 16 & US & Saddleback College, California \\
\hline 17 & US & $\begin{array}{l}\text { Texas A \& M University - Commerce } \\
\text { College of Business and Entrepreneurship }\end{array}$ \\
\hline 18 & US & California State University, Long Beach \\
\hline 19 & US & University of Notre Dame \\
\hline & & Asia Pacific Region (14 selected Universities)/ country \\
\hline 1 & Singapore & National university of Singapore \\
\hline 2 & Singapore & Nanyang Business School, Singapore \\
\hline 3 & China & University of Hong Kong \\
\hline
\end{tabular}


INTERNATIONAL JOURNAL OF ACADEMIC RESEARCH IN BUSINESS AND SOCIAL SCIENCES Vol. 8, No. 12, Dec, 2018, E-ISSN: 2222-6990 @ 2018 HRMARS

\begin{tabular}{|c|c|c|}
\hline 4 & $\begin{array}{l}\text { Hong Kong } \\
\text { China }\end{array}$ & Hong Kong University of Science and Technology \\
\hline 5 & Thailand & AIT School of Management \\
\hline 6 & $\begin{array}{l}\text { Hong Kong, } \\
\text { China }\end{array}$ & Chinese University of Hong Kong \\
\hline 7 & China & Tsinghua University, \\
\hline 8 & Australia & Monash University \\
\hline 9 & Australia & CQ University, Australia \\
\hline 10 & Australia & Australia National University \\
\hline 11 & Australia & Macquarie University, Sydney Australia \\
\hline 12 & Australia & University of Wollongong (UOW), Australia \\
\hline 13 & $\begin{array}{l}\text { New } \\
\text { Zealand }\end{array}$ & University of Auckland, New Zealand \\
\hline \multirow[t]{2}{*}{14} & Australia & Charles Sturt University, Sydney \\
\hline & & $\begin{array}{l}\text { European and African region } \\
\text { (22 selected universities) } \\
\text { Country }\end{array}$ \\
\hline 1 & Scotland & University of Glasglow, Scotland \\
\hline 2 & UK & University of London \\
\hline 3 & UK & The University of Exeter, UK \\
\hline 4 & UK & University of Strathclyde Business School, UK \\
\hline 5 & UK & University of Greenwich, UK \\
\hline 6 & UK & Essex Business School \\
\hline 7 & UK & University of Manchester \\
\hline 8 & UK & Warwick Business School \\
\hline 9 & UK & Anglia Ruskin University in Cambridge and Chelmsford \\
\hline 10 & Wales & University of Aberystwyth \\
\hline 11 & Spain & Universita Autònoma de Barcelona \\
\hline 12 & Spain & $\underline{\text { Universitat de Girona }}$ \\
\hline 13 & UK & Kent Business School \\
\hline 14 & Poland & Kozminski University \\
\hline 15 & Poland & University of Warsaw \\
\hline 16 & Portugal & Castelo Branco University of Applied Sciences \\
\hline 17 & Portugal & University of Minho \\
\hline 18 & Ireland & Independent College Dublin \\
\hline 19 & Scotland & University of Stirling \\
\hline
\end{tabular}


INTERNATIONAL JOURNAL OF ACADEMIC RESEARCH IN BUSINESS AND SOCIAL SCIENCES Vol. 8, No. 12, Dec, 2018, E-ISSN: 2222-6990 @ 2018 HRMARS

\begin{tabular}{|l|l|l|}
\hline 20 & Lithuanian & Utena University Of Applied Sciences \\
\hline 21 & Ireland & Galway-Mayo Institute of Technology (GMIT) \\
\hline 22 & South Africa & University of Cape Town \\
\hline
\end{tabular}

